\title{
DEVELOPING WRITING DESCRIPTIVE TEXT MATERIALS FOR THE TENTH GRADE STUDENTS OF TOURISM PROGRAM IN SMK NEGERI 1 SIDIKALANG
}

\author{
AN ARTICLE
}

Submitted in Partial Fulfillment of the Requirements for the Degree of Sarjana Pendidikan

By:

DEVI FITRIANI SAMSUL BAHRI

Registration Number: 2133121021

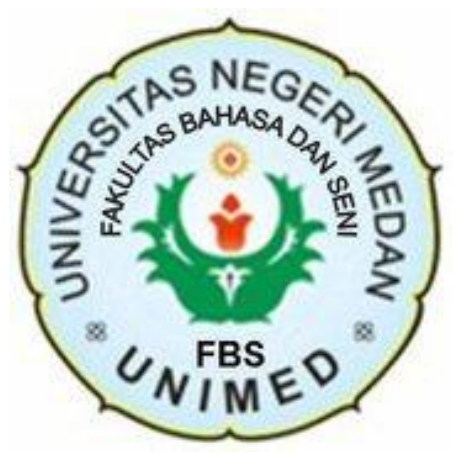

ENGLISH AND LITERATURE DEPARTMENT

FACULTY OF LANGUAGES AND ARTS

MEDAN STATE UNIVERSITY

2018 


\title{
ARTIKEL \\ DEVELOPING WRITING DESCRIPTIVE TEXT MATERIALS FOR THE TENTH GRADE STUDENTS OF TOURISM PROGRAM IN SMK NEGERI 1 SIDIKALANG
}

\author{
Disusun dan Diajukan oleh: \\ Devi Fitriani Samsul Bahri \\ Registration Number: 2133121021
}

Telah diverifikasi dan dinyatakan memenuhi syarat untuk diunggah pada jurnal online

Medan, Januari 2018

\section{Menyetujui}

Dosen Pembimbing I

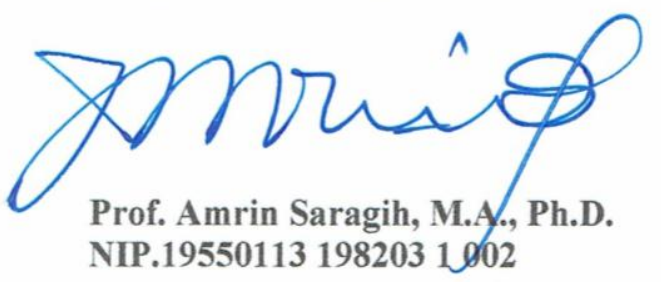

Dosen Pembimbing II

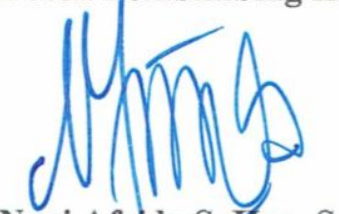

Neni Afrida S. \#rp, S.Pd., M.Hum.

NIP. 198204162008012012

Ka ${ }_{\text {Program Studi }}$

Pendidikan Bahasa Inggris

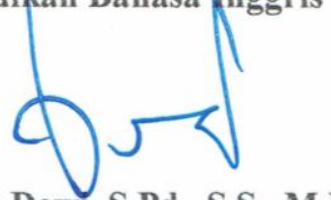

Nora Ronita Dewl, S.Pd., S.S., M.Hum.

NIP. 198005222008122003 


\title{
DEVELOPING WRITING DESCRIPTIVE TEXT MATERIALS FOR THE TENTH GRADE STUDENTS OF TOURISM PROGRAM IN SMK NEGERI 1 SIDIKALANG
}

\author{
* Devi Fitriani Samsul Bahri \\ ** Amrin Saragih \\ ** Neni Afrida Sari Harahap
}

\begin{abstract}
This study deals with the developing writing descriptive text for students of vocational school. The objective of the study is to develop the English writing materials to cope with the students' needs for grade X students of Tourism Program in SMKN 1 Sidikalang for better materials which are appropriate with the students' need of tourism program. The research was conducted by using Research and Development (R\&D) method. The subject of the research was 2017/2018 students of tenth grade of class X UPW 1 at SMKN 1 Sidikalang. The number of the students was 35 students. The data of this study was collected based on the questionnaire analysis, the interview analysis, the experts judgment and selective writing text. Need analysis questionnaire was calculated by using percentage to get the information of students' need before developing writing text materials particularly descriptive text. Expert judgment data was calculated by using criteria interval of expert judgment to know validity of writing materials which has been developed. The writing materials were in the form of writing text and writing skills which consisted of thirteen tasks. After the data analyzed, it was found that the expert's judgment result was 4.5 which had a very good criteria interval. The result of the research finds that the developed writing materials are relevant which cope with the students' need and appropriate to be used in teaching and learning.
\end{abstract}

Keywords: English writing materials, Tourism program, Research \& Development $(R \& D)$

*Graduate

** Lecturer 


\section{INTRODUCTION}

\section{Background of the Study}

In the terms of the development of science and technology, English has an important role for human life, by using English people will express their ideas, emotion, and desires, and it is used as a medium to interact with one another, to fulfil their daily need. English has been the most important language in international communication. The people all over the world speak the language when they meet one another in every international meeting, workshop, or conference. All countries in the world have set the language as one of the compulsory subject studied at school.

English has many functions, one of them as stated in the 2004 curriculum that English is means for the students to develop science, technology, culture and art, and the final objective of teaching and learning process is the students are expected to master the four skills of language: listening, speaking, reading, and writing. Writing is one of the best ways to improve the students' ability in mastery English as a communication tool. There are some reasons why writing is absolutely important. First, writing is one of the communication ways to communicate with other people in the world. Second, writing ability is required in almost in part of jobs. The last, writing can be assumed as one of the characteristics of an educated people. For this purpose the students are expected to be able to write descriptive text correctly, particularly for vocational school students. Furthermore in determining the students' academic achievement has been stated by the government in the statements of passing 
competence standard of writing skill for vocational school students stated that students are required to express the meaning of written simple personal and transactional text, formally or informally in daily life context. Thus, it means that writing English skill is very essential for the vocational school students to be mastered.

Vocational school is concerned with preparing students' ability in their major for working in the future, which means that the students of vocational school have to learn English for Specific Purpose (ESP) that is related to their targeted job in the future. English for Specific Purposes (ESP) needs to be taught because it is about how the teacher teaches the students based on their need and suitable from their program. The specification of English will help the learners to master English as they need in term of specific purpose they have (Hutchincon \& Water, 1986). The ESP student is particularly well disposed to focus on meaning in the subject-matter field. The learners come to the ESP class with a specific focus for learning, subject matter knowledge, and well-develop adult learning strategies. Through ESP, students will find some teaching materials which are related to their program in vocational school. 


\section{RESEARCH METHODOLOGY}

The research was conducted by using the Research and Development (R\&D). Educational R \& D is a development model in which the findings of research are used to design new products and procedures, which are systematically field-tested, evaluated, and refined until they meet specified criteria of effectiveness, qualitiy, or similar standard Borg \& Gall (2003: 569). Borg and Gall (2003: 572) state that if you plan to do and R \& D project for a thesis or dissertation, it is best to undertake a small-scale project that involves a limited amount of original instructional design. So, in this research, the ten stages of $\mathrm{R} \& \mathrm{D}$ were simplified into six stages because it depends on the research needed, those are : 1) Gathering data and information, 2) Analyzing Data, 3) Designing first draft of material, 4) Validating by Experts, 5) Revising, and 6) Final product.

The research place was at SMK Negeri 1 Sidikalang which consists of 35 students of Beauty study program. The source of data was curriculum, syllabus, existing materials, teachers' interview and students' questionnaires as qualitative data. The questionnaires and interview were the instruments of research that analyze descriptively.

In collecting the data the writer used questionnaires and interview. The first, the writer observed the syllabus and material, analyze the basic competence, students' worksheet, and the book. The second the writer did interview section to the English teacher to get information about students' problem which was faced in learning 
English especially writing, and also about the materials. The third, the writer gave the questionnaires to the students in order to get information about students' need in learning English. In this section the writer shared the questionnaire. So, the writer can get information toward students' need, students' problem in learning English, and also their interest in writing.

The flow chart of developing the materials

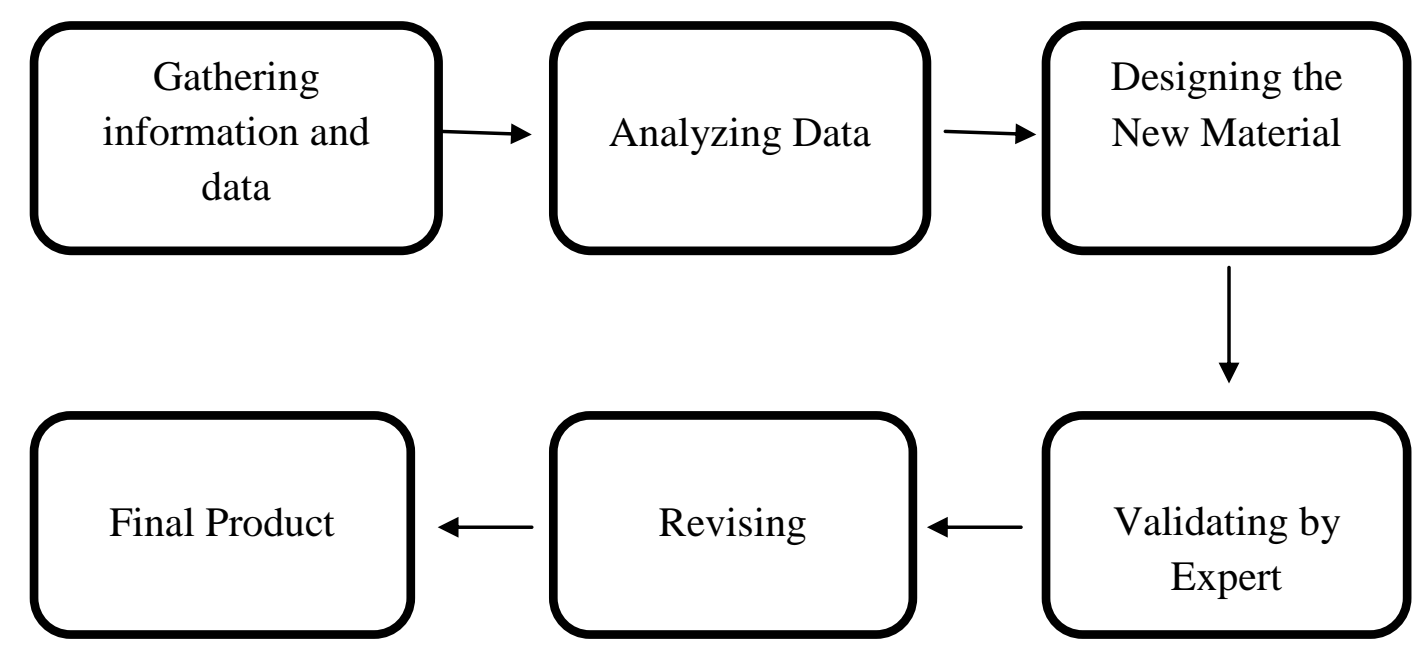

Figure 1.1 The flow chart of developing the materials 


\section{MATERIALS DEVELOPMENT}

The aim of this study was to develop appropriate English writing materials for grade $\mathrm{X}$ students of Tourism program at SMK Negeri 1 Sidikalang. In order to identify the needs of students of Tourism program, the writer administered the questionnaire to the students and did the interview to the English teacher. There were 15 questions that were answered by the students. It was the target needs and learning needs of the students.

Target needs is what the learners need to do in the target situations. It was consisted the term of necessities, lacks, and wants. In term of necessities, most of the students demand to master in writing skill and the English materials were aboutTourism. The lacks, most of the students were weak in writing skill because they were lack of vocabulary and also less of activities to support their practice in writing skill in the classroom. In term of wants, most of the students wanted English can help them to communicate fluently. Based on this result, the writer decided to make a topic in each unit related to Tourism context.

The next step was expert judgment process. The materials were evaluated by two experts. The criteria for expert judgment were based on the BSNP standard (Contents, language use, methodology and layout). In the process of experts judgments, there are some mistake should be replace, such as grammatical, spelling, and the vocabularies. Therefore, to get the quality of the product, the writer gave it to the validator to be validated. The validators came from English Lecturer from State 
University of Medan that was Indra Hartoyo, S.Pd., M.Hum. as the first validator and an English Teacher from SMK Negeri 1 Sidikalang that was Rosminar Rambe, S.Pd. as the second validator. As the result from the both validators evaluation got 4.5 or 90.3\% (Relevant) Which means the materials were developed was very relevant and cope with the students' need for grade X student of Tourism program SMK Negeri 1 Sidikalang .

\title{
CONCLUSION AND SUGGESTIONS
}

\author{
The Conclusion
}

The students of Tourism Program needed the specific material in writing text especially for descriptive text. In this study, the problems were they studied descriptive text but it was not appropriate to their major and also they needed the specific material which must make the motivation for them in doing writing materials. From the gathering data and information were started by observation of the book used in tenth grade students of Tourim Program in SMK Negeri 1Sidikalang used "Buku Bahasa Inggris" published by Kemendikbud (Kementrian Pendidikan dan Kebudayaan Republik Indonesia) in 2014. They only learned about "Visiting Tanjung Puting as an Ecotourism Destination" which less of appropriate in compiling the students' need and also less of writing task in the text book that used by the students which make the students less motivation in learning English. 


\section{The Suggestions}

After analyzing the data, the suggestions were drawn as the following

\section{Teacher}

In learning English for the vocational students, the teacher should find the specific material for the students. Because the students of tourism program are really close in explaining tourism spot or everything related to the tourism, so the teacher must dig their knowledge by writing everything they know about tourism spot it will motivate them to improve their skill especially in writing. The learning process can be successfull if the teacher can give the materials related to the students' program and also The teacher can apply "English for Specific Purposes" approach to apply in teaching English.

\section{Students}

The students must be active and wise if they want to increase their ability in writing English. If they could not find the specific material from the school especially their textbook, they should utilize the internet to find the specific material.

\section{Institution}

The new materials in this study has validated in term of relevancy, contents layout and linguistics features by an English for Specific Purposes expert, and the results show it is good, relevant, and feasible. So, it is suggested to for English teacher to use these materials to increase the tourism students' writing skill easier and faster, and for the other researcher who do the same study to develop the English 
writing materials for tourism in other skill in order to complete the skill needed by tourism students.

\section{REFERENCES}

Borg, R. Walterand Gall, M.D. 2003. Educational Research. New York: Longman

Brown, H. Douglas. 2004. Language Assessment: Principles and Classroom Practices. New York: Pearson Education, Inc

Gall, M.D., Joyce, P.G., Walter, R.G. 2003. Educational Research: An Introduction. United State of America: Pearson Education.

Hutchinson, T. \& Waters, A. (1987). English for Specific Purposes: A learningcentered approach. Cambridge: Cambridge University Press.

Pardiyono. 2007. Pasti Bisa! Teaching Genre-Based Writing.Yogyakarta:Andi

Richards, Jack C. 1990. Second language writing. New York: Cambridge University Press 